\title{
Authority of Regional Governments in Developing Investment in the Regional Investment
}

\author{
Salle $^{1}$, Lusiana ${ }^{2} \&$ La Ode Husen ${ }^{1}$ \\ ${ }^{1}$ Faculty of Law, Universitas Muslim Indonesia, Makassar, Indonesia \\ ${ }^{2}$ Postgraduate Doctoral Program, Universitas Jayabaya, Kota Jakarta Timur, Indonesia \\ Correspondence: La Ode Husen, Faculty of Law, Universitas Muslim Indonesia, Makassar, Indonesia. Tel: \\ 62-817-211-784. E-mail: laode.husen@umi.ac.id
}

Received: October 18, 2019

Accepted: November 14, 2019

Online Published: December 31, 2019

doi:10.5539/ass.v16n1p22

URL: https://doi.org/10.5539/ass.v16n1p22

\begin{abstract}
This research conducted with the aim of 1) To find and analyze the arrangements for the entry of foreign investors in investment in Indonesia, and 2) To find, analyze and develop the authority of the Regional Government in developing investments in regional investment. Legal research is a scientific activity, which is based on certain methods, systematics and thoughts that aim to learn something or some symptoms of a particular law, by analyzing it. In this case the research conducted by the author is research on legal protection of foreign investors in investment according to the Indonesian system.
\end{abstract}

Keywords: investment, regional investment, investors

\section{Introduction}

The meaning of independence in the current national development is that although the use of funds owned by the government takes precedence, national development is inseparable from outside assistance and cooperation, as long as the funds from outside parties function as a complement. In this globalization era, two aspects are needed to support this economic development. Internally, support is needed from the people of that country, the government as the organizer of the state, and externally, it is certainly needed support from foreign communities. Foreign communities can help support the development of a country's economy by fostering bilateral and multilateral cooperation, as well as the existence of fund injection support in the form of investment or foreign investment. As one component of capital flow, David Kairupan said:

"Foreign investment is considered a relatively stable capital flow compared to other capital flows, for example portfolio investment and foreign debt. Various policies have been carried out by the Indonesian government to achieve a goal which is to make the Indonesian people prosperous with the current economy, one of the ways is by investment (investment), both domestic and foreign investors".

Foreign investment alone can provide substantial benefits, for example by creating job vacancies for host country residents so as to increase income and living standards, create opportunities for cooperation with local companies so that they can share benefits, increase exports, thereby increasing the country's foreign exchange reserves and produce technology . Basically, in this era of globalization, investment can help maintain national economic stability in order to save the business sector which is suspected to be weak in the matter of capital.

Foreign investment must be in the form of a limited liability company with the status of an Indonesian legal entity so that foreign investors receive firmness in the legal status of the company that they are operating in and get certainty about the invested capital listed in Article 5 Paragraph (2) of Law no. 25 of 2007 concerning Capital Investment.

The role of investment in Indonesia is sufficient to support the development of economic life in accordance with the concept of law in economic activities and the ideals of Indonesia's economic law. To support investment in Indonesia, it is necessary to form an economic law with a set of regulations requiring a comprehensive study and a macro approach with accurate information for multidisciplinary purposes.

\section{Statement of the Problem}

1) How is the Arrangement of Foreign Investor Entry in Indonesia Investment? 
2) What is the Authority of the Regional Government in Developing Investment in the Regional Investment?

\section{Theoretical Framework}

\subsection{Legal Theories and Concepts}

\subsubsection{The State of Welfare Law Theory}

Djokosoetono said that "democratic rule of law" (democratischerechtsstaat), in fact this term is wrong, it should be used the term rechtsstaat. The same thing is used by Sudargo Gautama, in his book called: "... in a state of law, there is a limitation of state power over individuals ..., this term by British jurists is known as the rule of law." Ismail Suny also uses the terms of the rule of law in the sense of the rule of law, in the words: "... legal certainty does not exist in the full sense in our country, the rule of law is absent in Indonesia, our country is not a state of law, ...".

The concept of the rule of law according to Aristotle is a state that stands on a law that guarantees justice to its citizens. Justice, according to him, is a requirement for the achievement of happiness in life for citizens of a country. For Aristotle, who rules in a state is not a real person, but a fair mind, whereas the real ruler is only the holder of law and balance.

The concept of a welfare state is the basis for the position and function of the government (bestuurfunctie) in modern countries. The welfare state is the antithesis of the concept of a formal (classical) rule of law, which is based on the thought to exercise strict supervision of the administrators of state power.

\subsubsection{Legal System Theory}

Lawrence M. Friedman said that there were 3 (three) important pillars in the development of law, namely substance, structure, and culture. Ideally, the three pillars of national law development must go in harmony, harmony and balance because these three things are closely related to one another.

Every legal system, consisting of legal structure, legal substance, and legal culture. The legal substance must be used as a legal umbrella providing guidelines for the Government and Regional Governments in exercising the authority to issue licenses for investment principles so that investments can support investment in the regions and be sought for the greatest prosperity of the people, these legal norms include norms for state administration, administrative legal norms and even still strengthened by the existence of criminal law norms, in which all three are guidelines for the government and regional governments as implementers of decentralization in the capital investment sector.

\subsubsection{Regional Authority Theory}

Law No. 25 of 2007 concerning Capital Investment considers that to realize a just and prosperous society based on the Pancasila and the 1945 Constitution of the Republic of Indonesia, it is necessary to carry out sustainable national economic development based on economic democracy to achieve the objectives of the state. Explanation of Law No. 25 of 2007 concerning Capital Investment is said that the purpose of the State Government is to advance public welfare. This mandate has been spelled out in Article 33 of the 1945 Constitution of the Republic of Indonesia, which is also the constitutional mandate that underlies the formation of all laws and regulations in the economic field.

Authority must be based on existing legal provisions (the constitution), so that the authority is a valid authority. Thus, officials (organs) in issuing decisions are supported by the source of authority. F. A. M. Stroink explained that the source of authority can be obtained for officials or organs (institutions) of government by way of attribution, delegation and mandate. The authority of an organ (institution) of the government is an authority that is strengthened by positive law to regulate and maintain it. Without authority a right juridical decision cannot be issued.

\subsubsection{The Concept of General Welfare}

Legal certainty is important in order to realize public welfare in Indonesia considering that Indonesia is a state based on law (rechtsstaat) not based on mere power (machtsstaat). The creation of a rule of law also means the obedience of the rule of law in the activities of the State and its citizens. The rule of law elements include:

a. The primacy of legal rules or rule of law;

b. Equal status before the law;

c. Guaranteed human rights.

3.1.5 Legal Protection 
According to Satjipto Rahardjo, legal protection is an effort to protect one's interests by allocating a power to him to act in the framework of his interests. According to Philip Hadjon, that legal protection is divided into two types, namely:

1) Preventive legal protection, aimed at preventing disputes;

2) Repressive legal protection, aimed at resolving disputes.

According to Lili Rasjidi, and I. B. Wyasa Putra argues that the law can be used to realize protection that is not merely adaptive and flexible, but also predictive and anticipatory. Sunaryati Hartono's opinion said that law is needed for those who are weak and not yet strong socially, economically and politically to obtain social justice.

Legal protection provided by the Indonesian government to further enhance the confidence of foreign investors in investing their capital, one of which is making bilateral agreements with various countries of origin of investors, this investment agreement gives birth to several principles that are generally applicable in international relations.

Another Indonesian government action was to ratify the Conventional Conventions on Establishing the Multilateral Investment Guarantee (MIGA), based on Presidential Decree Number 1 of 1986. This gave a positive outlook to Indonesia by foreign investors, because with this the Indonesian party had provided a guarantee of protection the law for foreign investors on the risk of foreign investment in Indonesia. In addition, by issuing Law No. 25 of 2007 has provided a guarantee for legal protection and certainty for investors, both domestic and foreign.

\subsection{Domestic Investment and Foreign Investment}

\subsubsection{Capital Investment}

\subsubsection{The History of Investment Development in Indonesia}

The history of investment development is inseparable from the discussion of waves or periodization of investment, namely the pre-independence and post-independence periods.

The pre-independence period began in the 17th and 18th centuries. Through the policy of the Dutch East Indies government which permitted the entry of foreign capital from Europe to invest in mining.

In the post-independence period Indonesia legally began a new chapter in independently managing the country's economy in order to carry out national development, although investment remained stagnant due to Dutch colonialism and even worse during the Japanese occupation. In fact, during the next 17 years Indonesia only became an importer of capital goods and technology, none in the form of foreign direct investment. Until 1949 after Indonesia gained recognition of sovereignty from the Netherlands, the condition of foreign investment, especially foreigners who entered Indonesia, remained stagnant and only foreign investment from the Dutch government had begun to resume operations.

\subsubsection{Definition of Investment}

The term investment is a translation of the word investment, which comes from English. Investment is translated into Indonesian as "investment" or "investment". The term investment is often used in connection with international relations, while the term investment is more often found in various regulations. But basically the two terms have the same meaning. Investment is closely related to the economy in a country both in terms of financial and other social aspects. Investment or Investment is very influential on a country's financial balance sheet. Moreover, investment in an attractive field and drive investment itself is investment or investment in infrastructure.

The role of investment in the economy especially in developing countries such as Indonesia is therefore very strategic. Without adequate investment, do not expect high economic growth that results in economic prosperity for developing countries.

3.2.1.3 Types of Investment

\subsection{Domestic Investment}

Based on Law No. 25 of 2007 concerning Capital Investment Article 1 Paragraph 2 states that:

"Domestic Investment is the activity of investing in doing business in the territory of the Republic of Indonesia which is carried out by domestic investors using domestic capital."

Domestic investors can be carried out by Indonesian citizens (WNI), State business entities, and / or State governments that make investments in the territory of the Republic of Indonesia. Article 1 number 2 of the 
Capital Market Law states that Domestic Investment is an investment activity to conduct business in the territory of the Republic of Indonesia carried out by domestic investors using domestic capital. Whereas meant by domestic investors are Indonesian citizens, Indonesian business entities, The Republic of Indonesia, or regions that invest in the territory of the Republic of Indonesia (Article 1 number 5 of the Capital Market Law).

\subsection{Foreign Investment}

Foreign investment or foreign investment according to M. Suparmoko is an investment carried out by foreign capital owners in our country or gets a profit from the business carried out. In contrast to the statement made by M. Suparmoko which stated that Foreign Investment is an investment carried out by foreign capital owners.

Based on the above understanding, it can be concluded that Foreign Investment (PMA) is an investment activity in the territory of the Republic of Indonesia using foreign capital or joint venture with domestic investors. Foreign investment is a company in the form of a limited liability company with an Indonesian legal entity with foreign shareholders. It does not matter what percentage of the foreign share is important, while domestic investment is a company that is owned by a local entrepreneur. However, both are still an Indonesian company incorporated in Indonesian law and subject to Indonesian law.

3.2.2 The Authority of the Central and Regional Governments in Investment in Indonesia

The authority of the government in the administration of investment includes its scope across provinces as mandated in Article 30 paragraph (4) of the Investment Law.

Pursuant to Article 30 paragraph (7) of the Investment Law the government authority in the field of investment is determined. That authority includes:

a) Investment associated with non-renewable natural resources with a high level of risk of environmental damage;

b) Investment in the industrial sector which is a high priority on a national scale;

c) Investments related to the function of unifying and connecting between regions or their scope across provinces;

d) Investments related to the implementation of national defense and security strategies;

e) Foreign investment and investors who use foreign capital, which comes from other countries 'governments, which are based on agreements made by the Government and other countries' governments; and

f) Other investment fields are the Government's business according to the law.

\subsection{Regional Autonomy and Legislation}

\subsubsection{Regional Autonomy in the Framework of the Unitary Republic of Indonesia}

The implementation of regional autonomy, as a derivation of decentralization, besides constituting the mandate of the constitution, is also intended to meet the demands of the people as well as the efficiency and effectiveness of development in the framework of the Unitary State of the Republic of Indonesia.

From this description it can be seen that the objective of the implementation of decentralization is to avoid the accumulation of power on one party or in other words, decentralization is intended to carry out the distribution of power and to achieve democratic, efficient government and avoid centralizing power that can lead to a centralized government.

\subsubsection{Regional Regulations in the Regulatory System}

Regional Regulations are as defined by Law Number 10 of 2004 concerning Establishment of Legal Regulations, which are legislation formed by regional councils with the agreement of regional heads. The existence of regional regulations in the administration of regional government cannot be separated from the principle of decentralization carried out by the Central Government. Besides being contained in the 1945 Constitution (UUD 45) Article 18 paragraph (6), the authority to make regional regulations is also contained in Law Number 32 of 2004 concerning Regional Government and Law Number 10 of 2004 concerning Establishment of Legal Regulations. For the contents of the regional regulation, it is regulated in Article 12 of Law Number 10 of 2004 concerning Establishment of Legal Regulations as follows:

"The contents of the Regional Regulation are all the contents of the matter in the context of carrying out regional autonomy and co-administration tasks, and accommodating the special conditions of the region as well as further elaboration of the higher laws and regulations"

In the framework of exercising the authority to take care of the interests of the community, the Regional Head 
together with the Regional People's Representative Council stipulates the Regional Regulation. Regional Regulations serve as guidelines for Regional Governments in carrying out regional functions. In addition, regional regulations are instruments of legal protection for the people in the regions. Regional regulations also serve as instruments for controlling implementation, because the essence of regional autonomy, as stressed by Sukowiyono, is independence or zelfstandingheids as an autonomous region that has the right to regulate and manage its own household affairs, not a form of freedom of an independent government unit (onafhankelijkheid) The Drafting of Regional Regulation is prepared through certain stages, namely the stages of preparing academic texts / research reports and formulating draft formulations. Establishment of Legal Regulations is:

"the process of making Regional Regulations which basically starts from the planning, discussion, preparation techniques, formulation, discussion, ratification, enactment, and dissemination. In preparing the discussion and ratification of the draft regional regulation, it must be guided by the laws and regulations".

General legal principles in the formation of statutory regulations deductively apply to the formation of regional regulations, because regional regulations are an integral part of the concept of legislation. The principles of general law referred to according to A. Hamid S. Attamimi, are "Pancasila, a state based on law, and governance based on the constitution. This is in line with the main demands of political reform in 1999 is the creation of good governance in various public sectors. In order to achieve good governance, it is necessary to change the role of government in the administration of the country from its role as rowing to steering, which means that the government should ideally carry out the function of making policy and as a facilitator in development and more open up wider space for stakeholders in this matter investors to help with the development of an area.

\section{Discussion}

\subsection{Basic Investment Policy in Indonesia}

When talking about investment policy in Indonesia, of course it is very closely related to the closed and closed business sectors and open business fields with investment requirements. This happens because in general the host country limits and provides conditions for a business that can be planted with foreign capital, which is called a negative investment list (negative list), while the form of this restriction can be in the form of:

a) It is completely closed to foreign investment activities;

b) Open with joint enterprise requirements (limiting composition of share ownership);

c) Open with special conditions (partnerships, employment requirements, etc.)

The basic principles used in determining business fields that are closed and those that are open with requirements based on Article 5 and Article 6 of Presidential Regulation Number 76 of 2007 concerning Criteria and Requirements for Preparation of Business Fields that are closed and that are open with requirements in the investment field are simplification, compliance with international agreements or commitments, transparency, legal certainty, the unity of the territory of Indonesia as a single market.

Investor Rights and Obligations and Responsibilities Provisions regarding closed and open business fields with investments are currently regulated based on Presidential Regulation No. 39 of 2014 concerning List of closed business fields and open business sectors with requirements in the investment sector previously regulated by Presidential Regulation Number 36 of 2010. The consideration for changing the provision is an adjustment effort in the framework of implementing Indonesia's commitments within the ASEAN framework through the ASEAN Economic Community (AEC).

\subsection{Investment Institution (Investment Coordinating Board)}

In an effort to attract investment, the Investment Coordinating Board actively carries out investment promotion activities. Based on the mandate of the Law on Investment, the coordination of investment policy implementation is carried out by the Investment Coordinating Board (BKPM), which has the duties and functions of:

a) carry out tasks and coordinate the implementation of policies in the field of investment;

b) review and propose investment service policies;

c) establish norms, standards and procedures for implementing investment activities and services;

d) develop investment opportunities and potential in the regions by empowering business entities;

e) make a map of Indonesian investment;

f) promote investment; 
g) developing the investment business sector through investment management, including increasing partnerships, increasing competitiveness, creating healthy business competition, and disseminating information as broad as possible in the scope of investment administration;

h) help resolve various obstacles and consult problems faced by investors in carrying out investment activities;

i) coordinate domestic investors who carry out capital investment activities outside the territory of Indonesia and;

j) coordinate and carry out one-stop integrated services. BKPM experienced changes along with changes in national political and economic policies.

\subsection{Licensing and Public Services in Investment in Indonesia}

\subsubsection{Forms of Licensing Services Issued by the Government}

Along with the development of government in the region, various services have also developed. There are regions that have few types of services, but there are also regions that have relatively many types of services. Each local government has different types of services according to the characteristics and complexity faced by each region.

Permit is a document issued by a regional government based on regional regulations or other regulations which constitute proof of legality, certify the legal status or permissibility of a person or entity to carry out a particular business or activity. Licensing can take the form of registration, recommendation of certificates, determination of quotas and permits to carry out a business that usually must be owned or obtained by a company organization or a person before the person concerned can carry out an activity or action taken. As a one-sided legal act of the government, licensing raises rights and obligations for the applicant that need to be determined and regulated in legislation so that there is certainty and clarity, both regarding the requirements and also regarding the procedure for granting permits.

The forms of licensing issued by the government are:

\subsubsection{Dispensation}

Dispensation is a serious exception, that is an exception to the prohibition as a general rule. Giving favor is closely related to special circumstances of the event.

\subsubsection{License}

The name of the license seems appropriate for a permit in running a business, the permit does not guarantee that the licensee will not interfere in the company or line of business being carried out. Although the license provides a discretion for the business.

\subsubsection{Concession}

Always concessions regarding work related to the public interest must be strictly implemented. Therefore, the concessionaire both by law and by holding requirements, the concession holder is almost always obliged to carry out work that is permitted to him in a certain time and can be carried out with regular administration.

\subsubsection{Recommendation}

In addition to dispensations, licenses and concessions on licensing issues, there are also recommendations. Recommendations can be interpreted as a consideration given by the body or official authorized to be used in granting permits in a particular field. Recommendations are quite important instruments in the matter of licensing because recommendations are given by bodies or officials who have special competencies or capacities in certain fields, even based on expertise in a particular discipline. The issuance of recommendations is preceded by an application that can be rejected and the processing is carried out, just like issuing a permit. Somewhat different from a permit, a recommendation is something that does not directly have a tie. This means that the agency authorized to issue a permit can use recommendations as a reference or reference, but it is possible for officials or agencies authorized to issue licenses to use other considerations. However, given the recommendations issued by agencies or agencies that have the authority and expertise in certain fields, inevitably also heeded.

\subsubsection{Permission as a Monitoring Instrument}

To implement and enforce positive legal provisions requires authority, without authority no concrete juridical decisions can be made (there must be an authority or principle of legality), therefore permits must be based on the authority given by the legislation. The authority of the government in the area of licenses is in the form of discretionary power or in the form of free authority, in the sense that the government is given the authority to 
consider on the basis of its own initiative matters related to permits, for example consideration of:

1) What conditions allow a permit to be given to the applicant;

2) How to consider these conditions;

3) Juridical consequences that may arise from the granting of a permit or refusal of a permit are related to the limitations of the applicable laws and regulations;

4) What procedures must be followed or prepared for when and after the decision is given, both the acceptance and rejection of the permit.

\subsubsection{Principles for Licensing of Investment Principle}

Licensing services carried out by the government is one form of public service, so licensing activities must be carried out based on the general principles of good governance as a norm of behavior for government officials. The principles that form the basis of the Licensing conducted by the Regional Government are as follows:

1) The principle of legality, namely the implementation of the duties and authority of the government in providing services must be based on applicable laws and regulations.

2) The principle of public interest, namely the provision of services may not prioritize personal and / or group interests;

3) The principle of legal certainty, namely the guarantee of the realization of rights and obligations in the delivery of services;

4) The principle of equality of rights, namely the provision of services must not distinguish between ethnicity, race, religion, class, gender, and economic status;

5) The principle of balance of rights and obligations, namely the fulfillment of rights must be proportional to the obligations that must be carried out both by the giver and the recipient of the service;

6) The principle of professionalism, namely the service implementer must have competencies that are appropriate to the field of duty;

7) Participatory principle, namely increasing community participation in service delivery by taking into account the aspirations, needs and hopes of the community;

8) The principle of equality of treatment / non-discrimination, ie every citizen has the right to receive fair services;

9) The principle of openness, that is, each service recipient can easily access and obtain information about the desired service;

10) The principle of accountability, namely the process of service delivery must be accounted for in accordance with statutory provisions;

11) The principle of facilities and special treatment for vulnerable groups, namely providing facilities to vulnerable groups so as to create justice in service;

12) The principle of timeliness, i.e. the completion of each type of service is carried out on time in accordance with service standards;

13) The principle of speed, convenience, and affordability, that is, each type of service is carried out quickly, easily and affordably.

\subsubsection{Improving Service Quality Through One Stop Service}

\subsubsection{Public Service Criteria}

Public services are carried out in a series of activities that are simple, open, appropriate, complete, reasonable and affordable. In Menpan Decree No. 81 of 1993 emphasized that the implementation of public services must contain elements of:

1) Rights and obligations for service providers and recipients of public services must be clear and clearly known by each;

2) The regulation of each form of public service must be adjusted to the conditions of the needs and ability of the community to pay, based on the provisions of the applicable legislation while still adhering to efficiency and effectiveness;

3) The quality of processes and results of public services must be endeavored to provide accountable security, 
convenience, smoothness and legal certainty;

4) If public services provided by government agencies are forced to be expensive, the relevant government agencies are obliged to provide opportunities for the public to participate in carrying out them in accordance with applicable laws and regulations.

\subsubsection{Regional Policy in Implementing One Stop Service}

Regulation of the Minister of Home Affairs number 24 of 2006 concerning Guidelines for Organizing One-Stop Integrated Services, clarifies and emphasizes that the policy of providing licensing services in the regions must be implemented in an integrated one stop service. However, of the hundreds of local governments that have tried to implement one-stop services, it turns out that only a small number have succeeded in implementing the policy. That is, there are still very many local governments that fail / have not succeeded. The failure mostly concerns the apparatus HR readiness, service orientation which is very thick nuances of increasing local revenue), and support from the executive and legislative commitment which is still relatively low to implement the one stop service policy.

\subsection{Bali Provincial Investment and Licensing Agency}

\subsubsection{General Description of the Bali Province Investment and Licensing Agency}

Investment and Licensing Activity is one of the strategic activities to spur high economic growth. To spur high economic growth requires a large investment. Large investments require mobility of planned and integrated investment financing sources. Noting that the ability of the Provincial Government of Bali to finance development is very limited, the local government provides opportunities for the public and the private sector to participate more actively in economic development through investment activities.

During the period of 2008 - 2013 investment in the Province of Bali has increased as shown in Table 1.

Table 1. Development of Plans and Realization of Foreign Investment and Domestic Investment in Bali Province in 2008-2013

\begin{tabular}{|c|c|c|c|c|c|c|c|c|c|}
\hline \multirow{3}{*}{ No } & \multirow{3}{*}{ Year } & \multicolumn{4}{|c|}{ Plan } & \multicolumn{4}{|c|}{ Realization } \\
\hline & & \multicolumn{2}{|c|}{ Domestic Investment } & \multicolumn{2}{|c|}{ Foreign Investment } & \multicolumn{2}{|c|}{ Domestic Investment } & \multicolumn{2}{|c|}{ Foreign Investment } \\
\hline & & Project & $\begin{array}{l}\text { Investment } \\
\text { Value }\end{array}$ & Project & $\begin{array}{c}\text { Investment } \\
\text { Value }\end{array}$ & Project & $\begin{array}{c}\text { Investment } \\
\text { Value }\end{array}$ & Project & $\begin{array}{c}\text { Investment } \\
\text { Value }\end{array}$ \\
\hline 1 & 2008 & 10 & $1,185,133$ & 232 & $9,075,110$ & 2 & 28,991 & 54 & 735,068 \\
\hline 2 & 2009 & 9 & $10,655,865$ & 262 & $4,304,029$ & 6 & 50,838 & 96 & $2,098,161$ \\
\hline 3 & 2010 & 3,773 & $2,852,993$ & 83 & $2,503,801$ & 3,772 & $2,651,362$ & 75 & $4,210,160$ \\
\hline 4 & 2011 & 4,900 & $7,294,115$ & 40 & $6,966,171$ & 4,910 & $7,314,479$ & 165 & $4,386,969$ \\
\hline 5 & 2012 & 5,233 & $9,434,303$ & 261 & $7,598,500$ & 5,738 & $7,606,361$ & 295 & $4,478,765$ \\
\hline 6 & 2013 & 5,304 & $5,148,151$ & 246 & $6,805,163$ & 5,314 & $7,793,144$ & 457 & $3,634,973$ \\
\hline \multicolumn{2}{|c|}{ Total } & 19,229 & $36,570,560$ & 1,124 & $37,252,774$ & 19,742 & $25,445,175$ & 1,142 & $16,710,867$ \\
\hline
\end{tabular}

Source: BPMP Bali Province, November 2016

In the period 2008 to 2013, the total Foreign Investment Project Plan reached 1,124 projects with an investment of Rp. 29,654,274,000,000, while the total number of Domestic Investment Project Plans reached 19,229

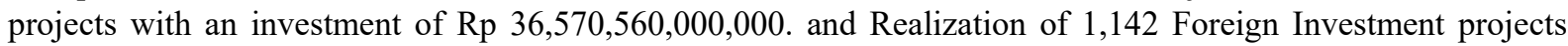
with an investment of Rp. 19,544,096,000,000 or $65.90 \%$ of the investment plan, while the realization of the Domestic Investment project was Rp. 19,742 Pieces with an investment of Rp. 25,445,175,000,000 or 69.57\% of the investment plan.

In the next five years (2013-2018) this condition is expected to be better. Based on the growth trend for the previous five years, the average investment growth in the next five years (2013-2018) is predicted to reach an average of Rp 12.21 trillion per year, assuming all the determinants of investment are running normally.

Efforts to equalize investment growth between regions have begun to show results, from 2003 to 2007, as a whole the realization of Foreign Direct Investment and Domestic Investment in Bali Province was still concentrated in Badung Regency, Denpasar City and Gianyar Regency. 2008 to 2013 investments have begun to grow in Buleleng Regency and Tabanan Regency, as stated in table 2 below: 
Table 2. Development of Realization of Foreign Investment and Domestic Investment Viewed from Location in 2008-2013

\begin{tabular}{ccccc}
\hline No & Location & Project & Investment Value of Investment / Domestic Investment (Rp) & \% \\
\hline 1 & Badung Regency & 2,692 & $23,081,825,000,000$ & 51,30 \\
2 & Denpasar City & 5,518 & $10,472,749,000,000$ & 23,27 \\
3 & Buleleng Regency & 2,822 & $3,185,210,000,000$ & 7,07 \\
4 & Tabanan Regency & 4,273 & $3,307,018,000,000$ & 7,35 \\
5 & Gianyar Regency & 1,900 & $2,815,255,000,000$ & 6,25 \\
6 & Karangasem Regency & 1,359 & $956,344,000,000$ & 2,12 \\
7 & Klungkung Regency & 596 & $524,976,000,000$ & 1,16 \\
8 & Jembrana Regency & 868 & $529,071,000,000$ & 1,17 \\
9 & Bangli Regency & 854 & $116,823,000,000$ & 0,25 \\
& Total & 20,882 & $44,989,271,000,000$ & 100 \\
\hline
\end{tabular}

Source: BPMP Bali Province, November 2016

Viewed from the country of origin of investment in the last five years, the top 10 countries that have realized investments in a row in accordance with the size of the investment are a combination of countries, British Virgin island, Singapore, England, South Korea, the Netherlands, France, Australia, Japan and the United States as stated in Table 3.

Table 3. Development of Realization of Foreign Investment Viewed from the Country of Origin of Investment 2008 - 2013 (Top 10)

\begin{tabular}{ccc}
\hline No & Country & Investment Value $(\mathrm{Rp})$ \\
\hline 1 & Combined countries & 6.855 .654 .818 .600 \\
2 & British Virgin Island & 2.747 .634 .440 .900 \\
3 & Singapore & 2.569 .933 .329 .200 \\
4 & British & 1.636 .509 .056 .300 \\
5 & South Korean & 543.949 .650 .700 \\
6 & Netherlands & 283.574 .783 .400 \\
7 & France & 255.730 .593 .800 \\
8 & Australia & 236.359 .651 .600 \\
9 & Japan & 148.990 .583 .500 \\
10 & USA & 94.506 .383 .600 \\
\hline
\end{tabular}

In its development the investment climate in Bali for the better. This can be seen from the average investment growth in the five years since (2013-2018) reaching an average of Rp 12.21 trillion per year, assuming all the determinants of investment are running normally. Efforts to equalize investment growth between regions have shown results, from 2003 to 2007 the overall realization of PMA and PMDN in Bali Province was still concentrated in Badung Regency, Denpasar City and Gianyar Regency.

A factor that strongly supports this investment climate is the aspect of the substance of the law that guarantees legal certainty for foreign and domestic investment, as well as from the aspect of the legal structure that the government provides for security stability in investing. Meanwhile, from the aspect of legal culture, it can be seen from the brush of Balinese people that they always provide an attitude of tolerance and open attitude to investors who come to Bali to invest and grow and develop businesses.

\subsubsection{Authority of Granting Investment Principle License}

The granting of principle licenses in the field of investment is carried out by the Bali Provincial Investment and Licensing Agency, the Governor gave delegation of authority for licensing and non-licensing of government affairs in the investment sector which is the authority of the Regency / City Government of the Province of Bali to the Head of the Agency.

Implementation of the granting of principle investment licenses through the One Stop Integrated Service (PTSP) 
in the Field of Investment, is the activity of licensing and non-licensing activities based on delegation or delegation of authority from institutions or agencies that have Licensing and Non-licensing authority, the management process starts from the application stage up to the licensing stage the stage of publication of documents carried out in one place.

\subsubsection{Licensing Room and Type}

The scope of the granting of the principle of investment permit is open to all business sectors for investment activities, except for business fields or types of business that are declared closed and open with conditions stipulated by laws and regulations. Types of investment licensing services include:

1) investment Principle License;

2) business permit;

3) other permits in the context of implementing investment in accordance with statutory provisions.

Types of non-licensing services are:

1) regional incentives;

2) information and complaint services;

3) certain documents or other certifications required by investors for the smooth running of their business in accordance with applicable regulations.

\subsubsection{Mechanisms and Procedures for Granting Permits in Investment in Bali}

The mechanism is a network of procedures that makes things move regularly and in an integrated manner, therefore the need for regulation of the mechanism and procedure for granting principle permits for investment. The mechanism and procedure for granting principle licenses refers to a one-stop integrated service policy that is carried out in an integrated manner in a unified process, based on delegation or delegation of authority from institutions or agencies that have licensing and non-licensing authority whose management process starts from the application stage up to the stage of application publication of documents carried out in one place. There are only 2 licensing procedures at the Coordinating Board for Investment in M namely the Principle License, to start a business in Indonesia. After the company is ready for production / operation, a Business Permit is issued, to issue a business license, the company must have an operational permit from the local government as well as from the relevant ministries.

\section{Inclusion}

1) Regulations on the Entry of Foreign Investors in Investments in Indonesia are regulated in Law No. 25 of 2007 concerning Capital Investment, concerning Investment Procedures (Investments) regulated through Presidential Decree No. 97 of 1993, then was amended by Presidential Decree No. 115 of 1998 and subsequently underwent changes with RI Presidential Decree No. 117 of 1999, was the second amendment to Presidential Decree No. 97 of 1993 concerning Investment Procedures. The change was made by the government in order to further improve investment licensing services. Some important matters related to the government policy include:

a. Authority in granting approval and licensing for investment implementation. For applications for investment in the context of Domestic Investment, they can be delegated to the Governor of the Regional Head;

b. To carry out further delegation of authority as referred to above, the Governor of the Province of the Province appoints the Chairman of the Regional Investment Coordinating Board;

c. The procedures for investment in the context of Domestic Investment are referred to, further stipulated by the State Minister of Investment / Head of the Investment Coordinating Board.

Foreign Investment is determined, that:

a. The authority to grant investment approval in the framework of Foreign Investment as regulated in Law No. 1 of 1967 and was amended by Law No. 11 of 1970 was delegated by the Minister of State / Investment to the Investment Coordinating Board to the Minister of Foreign Affairs and the Governor of the Provincial Region;

b. Specifically to the Governor, the Regional Head shall also be given the delegation of authority to grant licenses for the implementation of investment, as long as an agency has not been established to handle investment in the Regency and City Regions;

c. To carry out further delegation of authority to the Minister of Foreign Affairs, the Minister of Foreign Affairs assigns the Chief Representative of the Republic of Indonesia. As for the exercise of delegation of authority to the Governor of the Regional Head, the Governor of the Provincial Region shall assign the Chairman of the 
regional Investment Coordinating Board.

2) The Authority of Regional Governments in Developing Investment in the Regional Investment is regulated in the Law. No. 23 of 2014 concerning Regional Government and Government Regulation Number 38 of 2007 concerning Division of Government Affairs between the Government, Provincial Government, and Regency / City Government. The division of authority for granting investment permits between the central government and regional governments:

a. The granting of PMDN licensing is issued by the Regency / City Government

b. The granting of Domestic Investment Licenses for Cross-district issuance is issued by the Provincial Government

c. The granting of licenses for Cross-Province Domestic Investment is issued by the RI / Central Investment Coordinating Board

d. The granting of Foreign Investment Licensing is issued by the RI / Central Investment Coordinating Board (can be seen in accordance with Perka BKPM RI Number 15 Year 2015 concerning Guidelines and Procedures for Licensing and Non-Licensing Article 5,6,7,8,9)

\section{References}

Aburaera, S., Husen, L., Mustamin, H., \& Masturi, R. (2017). The Natural of Justice in the Procurement of Land for General Interests in the National Development Framework. Imperial Journal of Interdisciplinary Research (IJIR), 3(9), 155-160. Retrieved from https://scholar.google.com/scholar?cluster=12912775242 488355209\&hl $=\mathrm{id} \&$ as_sdt $=2005 \&$ sciodt $=0,5$

Akbar, A., \& Husen, L. (2018). Implication of Trims Agreements in International Trade and Relationship with Legal Development in Indonesia. International Journal of Science and Research (IJSR), 7(1), 1484-1488.

Attamimi, A., \& Hamid S. (1990). Peranan Keputusan Presiden Republik Indonesia dalam Penyelenggaraan Pemerintahan Negara: Suatu Studi Analisis Mengenai Keputusan Presiden yang Berfungsi Pengaturan dalam Kurun Waktu PELITA I - PELITA IV. (Doctor Disertasi). Universitas Indonesia, Jakarta. Retrieved from https://scholar.google.com/scholar?cluster=14400336396933771446\&hl=id\&as_sdt=2005\&sciodt=0,5

Effendi, T. (2004). Tingkatkan Pelayanan Publik. Jakarta: Suara Pembaruan. Retrieved from https://scholar.google.com/scholar?cluster $=16273608021736811895 \& \mathrm{hl}=\mathrm{id} \&$ as_sdt=2005\&sciodt $=0,5$

Friedman, L. M. (1984). American Law (Wisnu Basuki, Trans.). New York: W. W. Norton \& Company. Retrieved from https://scholar.google.com/scholar?cluster=7591442974580323577\&hl=id\&as_sdt=2005\& sciodt $=0,5$

Gautama, S. (1983). Pengertian tentang Negara Hukum. Bandung: PT. Alumni. Retrieved from https://scholar.google.com/scholar?cluster $=8149544078000162190 \& \mathrm{hl}=\mathrm{id} \&$ as_sdt $=2005 \& \mathrm{sciodt}=0,5$

Hadjon, P. M. (1987). Perlindungan Hukum Bagi Rakyat di Indonesia: Sebuah Studi tentang Prinsip-Prinsipnya, Penanganannya oleh Peradilan dalam Lingkungan Peradilan Umum dan Pembentukan Peradilan Administrasi Negara. Surabaya: PT. Bina Ilmu. Retrieved from https://scholar.google.com/scholar?cluster= $17850673424617057991 \& \mathrm{hl}=\mathrm{id} \&$ as_sdt $=2005 \&$ sciodt $=0,5$

Hardiyansyah. (2011). Kualitas Pelayanan Publik: Konsep, Dimensi, Indikator dan Implementasinya. Yogyakarta: Gava Media. Retrieved from https://scholar.google.com/scholar?cluster=1452193550980763 4109\&hl=id\&as_sdt $=2005 \&$ sciodt $=0,5$

Hartono, S. (1991). Politik Hukum Menuju Satu Sistem Hukum Nasional. Bandung: PT. Alumni. Retrieved from https://scholar.google.com/scholar?cluster $=4086480370125841310 \& \mathrm{hl}=\mathrm{id} \&$ as_sdt $=2005 \&$ sciodt $=0,5$

Husen, L. (2005). Hubungan Fungsi Pengawasan Dewan Perwakilan Rakyat dengan Badan Pemeriksa Keuangan dalam Sistem Ketatanegaraan Indonesia. Bandung: CV. Utomo. Retrieved from https://scholar.google.com/scholar?cluster=16897742550831210736\&hl=id\&as_sdt=2005\&sciodt=0,5

Husen, L. (2009). Hukum Pajak \& Hak Privilege. Bandung: CV. Utomo. Retrieved from https://scholar.google.com/scholar?cluster=12474304775076119223\&hl=id\&as_sdt=2005\&sciodt=0,5

Husen, L., Rahman, S., Sampara, S., \& Sindawa. (2017). The Natural Village Government It Self State Laws System In Indonesia. Imperial Journal of Interdisciplinary Research (IJIR), 3(6), 726-731.

Husen, L., Sampara, S., Rahman, S., \& Cakkari, S. (2017). The Implementation of Regional Head Election Itself Directly In Local Governance System In Indonesia. Journal of Humanities and Social Science, IOSR, 22(9), 
53-58.

Irawan, \& Suparmoko, M. (2002). Ekonomika Pembangunan (6th ed.). Yogyakarta: CV. Andi Offset. Retrieved from https://scholar.google.com/scholar?cluster=10959570422725472315\&hl=id\&as_sdt=2005\&sciodt=0,5

Jalil, H., Husen, L., Abidin, A., \& Rezah, F. S. (2017). Hukum Pemerintahan Daerah dalam Perspektif Otonomi Khusus. Makassar: CV. Social Politic Genius (SIGn). Retrieved from https://scholar.google.com/scholar? cluster $=12960993546660696607 \& \mathrm{hl}=\mathrm{id} \& a s \_s d t=2005 \&$ sciodt $=0,5$

Kairupan, D. (2013). Aspek Hukum Penanaman Modal Asing di Indonesia. Jakarta: Kencana Prenada Media Group. Retrieved from https://scholar.google.com/scholar?cluster=16425101400737594841\&hl=id\&as $\mathrm{sdt}=2005 \&$ sciodt $=0,5$

Kusnardi, M., \& Ibrahim, H. (1998). Pengantar Hukum Tata Negara Indonesia. Jakarta: CV. Sinar Bakti. Retrieved from https://scholar.google.com/scholar?cluster=10484513344076425116\&hl=id\&as_sdt=2005\&sciodt=0,5

Law of the Republic of Indonesia Number 10 of 2004 (Law No. 10 of 2004) concerning Establishment of Legal Regulations. State Gazette of the Republic of Indonesia, Number 53 of 2004. Supplement to the State Gazette of the Republic of Indonesia, Number 4389.

Law of the Republic of Indonesia Number 25 of 2007 (Law No. 25 of 2007) concerning Capital Investment. State Gazette of the Republic of Indonesia, Number 67 of 2007. Supplement to the State Gazette of the Republic of Indonesia, Number 4724.

Majid, M., Husen, L., \& Pasamai, S. (2018). General Election Of The Regional Head In The Local Government System (A Study in Makassar). Journal of Humanities and Social Science, IOSR, 23(5), 87-94.

Rachbini, D. J. (2008). Arsitektur Hukum Investasi Indonesia. Jakarta: PT. Indeks. Retrieved from https://scholar.google.com/scholar?cluster=15328444940077409970\&hl=id\&as_sdt=2005\&sciodt=0,5

Rahardjo, S. (2003). Sisi-Sisi Lain dari Hukum di Indonesia. Jakarta: Kompas. Retrieved from https://scholar.google.com/scholar?cluster=1277766720390918811\&hl=id\&as_sdt=2005\&sciodt=0,5

Rahman, S, Husen, L, \& Salle. (2017). Proper Government Role In Land Procurement For Public Interests In Indonesia. Imperial Journal of Interdisciplinary Research (IJIR), 3(5), 918-923.

Rasjidi, L., \& Putra, I. B. W. (1993). Hukum Sebagai Suatu Sistem. Bandung: PT. Remaja Rosdakarya. Retrieved from https://scholar.google.com/scholar?cites $=14465486762464529582 \&$ as_sdt=2005\&sciodt $=0,5 \& \mathrm{hl}=\mathrm{id}$

Razak, A. (2013). Hukum Pelayanan Publik. Makasar: Arus Timur.

Regulation of the Minister of Home Affairs Number 24 of 2006 (24 of 2006) concerning Guidelines for Organizing One-Stop Integrated Services.

Ropke, J. (1986). Kebebasan yang Terhambat: Perkembangan Ekonomi dan Perilaku Kegiatan Usaha di Indonesia. Jakarta: PT. Gramedia Pustaka Utama. Retrieved from https://scholar.google.com/scholar? cluster $=2893241784723552109 \& \mathrm{hl}=\mathrm{id} \&$ as_sdt $=2005 \&$ sciodt $=0,5$

Salle. (2019). Hukum Kontrak: Teori dan Praktik. Makassar: CV. Social Politic Genius (SIGn). Retrieved from https://books.google.co.id/books?id=rDedDwAAQBAJ\&lr=\&hl=id\&source=gbs_navlinks_s

Salle, Husen, L., \& Sampara, S. (2019). Legal Politics for the Establishment of Regional Regulations in Realizing the Development of the National Legal System. International Journal of Science and Research (IJSR), 8(2).

Sampara, S., \& Husen, L. O. (2012). Metodologi Penelitian Hukum. Makassar: Kretakupa Print. Retrieved from https://scholar.google.com/scholar?cluster $=6374265246463510353 \& \mathrm{hl}=\mathrm{id} \&$ as_sdt=2005\&sciodt=0,5

Sedarmayanti. (2000). Tata Kerja dan Produktivitas Kerja: Suatu Tinjauan dari Aspek Ergonomo atau Kaitan antara Manusia dengan Lingkungan Kerjanya. Bandung: CV. Mandar Maju.

Spelt, N. M., \& Berge, J. B. J. M. ten. (1993). Pengantar Hukum Perizinan (Philipus M. Hadjon Ed.). Surabaya: Yuridika. Retrieved from https://scholar.google.com/scholar?cluster=2780621115713458683\&hl=id\&as_sdt $=2005 \& \operatorname{sciodt}=0,5$

Sukowiyono. (2006). Otonomi Daerah dalam Negara Hukum Indonesia: Pembentukan Peraturan Daerah Partisipatif. Jakarta: Faza Media. Retrieved from https://scholar.google.com/scholar?cluster=1753291 479414370647\&hl=id\&as_sdt=2005\&sciodt=0,5 
Sumantoro. (1986). Hukum Ekonomi. Jakarta: UI Press. Retrieved from https://scholar.google.com/scholar?cluster=6053350231617948835\&hl=id\&as_sdt=2005\&sciodt=0,5

Suny, I. (1982). Mencari Keadilan: Sebuah Otobiografi. Jakarta: Ghalia Indonesia. Retrieved from https://scholar.google.com/scholar?cluster $=4026416320458150295 \& \mathrm{hl}=\mathrm{id} \& \mathrm{as} \_\mathrm{sdt}=2005 \& \mathrm{sciodt}=0,5$

Thalib, A. R. (2006). Wewenang Mahkamah Konstitusi dan Aplikasinya dalam Sistem Ketatanegaraan Republik Indonesia. Bandung: PT. Citra Aditya Bakti. Retrieved from https://scholar.google.com/scholar?cluster=13243319140374903978\&hl=id\&as_sdt=2005\&sciodt=0,5

Tjandra, W. R. (2014). Hukum Sarana Pemerintahan. Jakarta: Cahaya Atma Pustaka. Retrieved from https://scholar.google.com/scholar?cluster $=8546441865987487047 \& \mathrm{hl}=\mathrm{id} \& \mathrm{as} \_\mathrm{sdt}=2005 \& \mathrm{sciodt}=0,5$

Wahyono, P. (1984). Guru Pinandita: Sumbangsih untuk Prof. Djokosoetono, SH. Jakarta: UI Press. Retrieved from https://scholar.google.com/scholar?cluster=12510059999459351167\&hl=id\&as_sdt=2005\&sciodt=0,5

Wasistiono, S., \& Wiyoso, Y. (2009). Meningkatkan Kinerja Dewan Perwakilan Rakyat Daerah (DPRD). Bandung: Fokus Media. Retrieved from https://scholar.google.com/scholar?cluster $=18275855882486$ $682447 \& \mathrm{hl}=\mathrm{id} \&$ as_sdt $=2005 \&$ sciodt $=0,5$

\section{Copyrights}

Copyright for this article is retained by the author(s), with first publication rights granted to the journal.

This is an open-access article distributed under the terms and conditions of the Creative Commons Attribution license (http://creativecommons.org/licenses/by/4.0/). 